\title{
PENGEMBANGAN MODUL FISIKA DENGAN PENDEKATAN KETERAMPILAN PROSES SAINS PADA MATERI LISTRIK DINAMIS UNTUK MENINGKATKAN KEMAMPUAN BERPIKIR KREATIF SISWA KELAS X SMA
}

\author{
Ayang Kinasih ${ }^{1}$, Widha Sunarno ${ }^{2}$ dan Sukarmin ${ }^{3}$ \\ ${ }^{1}$ Magister Pendidikan Sains, Fakultas Keguruan dan Ilmu Pendidikan, Universitas Sebelas Maret \\ Surakarta, 57126, Indonesia \\ kinasih.ayang@student.uns.ac.id \\ ${ }^{2}$ Magister Pendidikan Sains, Fakultas Keguruan dan Ilmu Pendidikan, Universitas Sebelas Maret \\ Surakarta, 57126, Indonesia \\ widhasunarno@staff.uns.ac.id \\ ${ }^{3}$ Magister Pendidikan Sains, Fakultas Keguruan dan Ilmu Pendidikan, Universitas Sebelas Maret \\ Surakarta, 57126, Indonesia \\ sukarmin67@staff.uns.ac.id
}

\begin{abstract}
Abstrak
Karakteristik ilmu fisika adalah ilmu yang di dalamnya terdapat prinsip, hukum, dan konsep. Proses untuk mendapatkan prinsip, hukum, dan konsep diperlukan metode ilmiah. Pengembangan bahan ajar yang relevan berdasarkan metode ilmiah diperlukan agar pembelajaran menjadi lebih bermakna sehingga dapat memaksimalkan hasil belajar. Penelitian ini bertujuan untuk: 1) mendeskripsikan cara penyusunan modul fisika melalui pendekatan keterampilan proses sains hasil pengembangan 2) menganalisis kelayakan modul fisika melalui pendekatan keterampilan proses sains yang dikembangkan 3) efektivitas modul fisika dengan pendekatan keterampilan proses sains untuk meningkatkan kemampuan berpikir kreatif dan hasil belajar siswa kelas X SMA. Jenis penelitian ini adalah penelitian dan pengembangan (Research and Development) termodifikasi dari Thiagarajan (1974), Pengembangan dilakukan dengan mengacu pada model 4-D dengan tahapan Define, Design, Develop, dan Disseminate. Instrumen yang digunakan adalah angket, lembar observasi, dan tes. Uji lapangan operasional menggunakan one group pretest-posttest design. Analisis data yang digunakan pada tahap define adalah analisis data deskriptif, pada tahap design dengan analisis KD, pada tahap develop untuk data hasil validasi modul menggunakan nilai cut off yang dikonversi menjadi kategori kualitas dengan pedoman skor skala 4 dan data kemampuan berpikir kreatif (hasil belajar kognitif) menggunakan uji t berpasangan dan dihitung dengan $n$-gain ternormalisasi, dan pada tahap disseminate menggunakan nilai cut off yang dikonversi menjadi kategori kualitas dengan pedoman skor skala 4. Berdasarkan analisa data diperoleh hasil penelitian dan pengembangan sebagai berikut: 1) modul Pembelajaran fisika dengan pendekatan keterampilan proses sains pada materi listrik dinamis dikembangkan berdasarkan komponen pembelajaran melalui pendekatan keterampilan proses sains dengan format kriteria modul yang diadaptasi dari pendapat Vembriarto dan merujuk pada standar yang telah ditetapkan BSNP tentang standar pengembangan modul dan buku teks pelajaran dengan model pengembangan modul menggunakan model 4-D meliputi define, design, develop, and disseminate, 2) kelayakan modul fisika dengan pendekatan keterampilan proses sains setelah dilakukan uji coba produk awal, uji coba lapangan terbatas, uji lapangan operasional, dan diseminasi didapatkan rata-rata persentase sebesar $77,87 \%$ yang dikategorikan "Baik", 3) efektivitas modul fisika dengan pendekatan keterampilan proses sains pada materi listrik dinamis dapat meningkatkan kemampuan berpikir kreatif (hasil belajar kognitif) siswa dengan nilai $N$-Gain sebesar 0,7 dikategorikan "Sedang".
\end{abstract}

Kata Kunci: Penelitian dan Pengembangan, Modul, Keterampilan Proses Sains, dan Kemampuan Berpikir Kreatif. 


\section{Pendahuluan}

Ilmu Fisika adalah ilmu yang mempelajari gejala alam dan dijelaskan ke dalam bahasa matematika. Karakteristik ilmu fisika seperti Ilmu Pengetahuan Alam lainnya adalah ilmu yang di dalamnya terdapat prinsip, hukum, dan konsep. Namun demikian, dalam proses untuk mendapatkan prinsip, hukum dan konsep diperlukan metode ilmiah. Metode ilmiah tidak dapat dipisahkan dari proses pembelajaran fisika, karena dengan metode ilmiah siswa dapat dituntun untuk menemukan prinsip, hukum, dan konsep secara mandiri.

Peraturan Menteri Pendidikan dan Kebudayaan Nomor 65 Tahun 2013 tentang Standar Proses menerangkan bahwa karakteristik kompetensi beserta perbedaan lintasan perolehan turut serta mempengaruhi karakteristik standar proses. Untuk memperkuat pendekatan ilmiah, tematik terpadu, dan tematik perlu diterapkan pembelajaran berbasis penyingkapan / penelitian.

Gambaran dari hasil studi internasional, yakni PISA (Programme for International Student Assessment) menyatakan bahwa pada tahun 2012 skor yang dicapai anak Indonesia dalam bidang sains masih di bawah rata-rata skor internasional, yakni 382 (skor rata-rata internasional adalah 501). Pencapaian ranking anak Indonesia dalam bidang sains berada pada urutan ke-64 dari 65 negara peserta. Sedangkan TIMSS (Trends in International Mathematics and Science Study) memperlihatkan bahwa pada tahun 2011 pencapaian skor sains anak Indonesia adalah 406, sedangkan skor rata-rata Internasional adalah 500. Ranking anak Indonesia dalam bidang sains berada pada posisi ke 40 dari 42 negara peserta.

Pembelajaran Fisika pada siswa SMA tidak hanya sekedar mempelajari prinsip, hukum, dan konsep saja, namun sudah mulai diberikan aplikasi-aplikasi yang dapat mereka kembangkan untuk kemajuan teknologi yang saat ini sudah semakin maju. Selain itu, dengan pembelajaran Fisika, siswa dapat membiasakan diri bersikap ilmiah untuk diterapkan dalam bersikap pada kehidupan sehari-hari mereka.
Namun demikian, agar siswa terbiasa dengan sikap ilmiah, maka pembelajaran fisika di sekolahpun harus menggunakan pendekatan pembelajaran yang mendukung mereka untuk terbiasa bersikap ilmiah.

Tujuan dari setiap kurikulum adalah untuk meningkatkan seluruh aspek kemampuan siswa dengan maksimal. Dalam hal ini, aspek peningkatan kemampuan tidak hanya terkonsentrasi pada peningkatan pengetahuan saja, namun juga pada aspek sikap dan keterampilan. Untuk itu, dalam pelaksanaannya, pendekatan pembelajaran yang akan digunakan adalah keterampilan proses sains. Pembelajaran dengan menggunakan pendekatan ini, membuat siswa terbiasa bersikap ilmiah, karena proses pelaksanaan keterampilan proses sains sesuai dengan proses pelaksanaan metode ilmiah.

Hasil Ujian Nasional (BSNP SMA/MA T.P 2013/2014) di SMA Negeri 1 Sekampung tahun pelajaran 2013/2014 pada materi listrik dinamis lebih rendah dibandingkan dengan nilai provinsi Lampung dan Nasional. Hal ini terlihat dari daya serap siswa pada tingkat nasional sebesar 54,80; di tingkat provinsi (Lampung) sebesar 46,70; dan di tingkat sekolah sebesar 23,00 yang merupakan nilai terendah diantara semua kompetensi materi UN. Rendahnya hasil UN tersebut, menjadi salah satu bukti bahwa banyak siswa yang belum bisa memahami materi listrik dinamis dengan baik.

Data hasil analisis kebutuhan guru dengan koresponden guru Sekolah Menengah Atas Negeri 1 Sekampung Lampung Timur, menyatakan bahwa di SMA N 1 Sekampung memerlukan bahan ajar berdasarkan kurikulum KTSP. Selain itu juga, perlu tersedianya bahan ajar yang sesuai dengan kurikulum KTSP secara memadai dalam bentuk cetak, pembelajaran belum menggunakan pendekatan keterampilan proses sains, belum melatih siswa pada keterampilan berpikir kreatif, dan materi pada bahan ajar yang digunakan belum memuat materi yang lengkap.

Guru kurang memperhatikan keterampilan berpikir kreatif siswa, hal ini terbukti dalam proses pembelajaran metode pembelajaran yang diterapkan belum melatih 
keterampilan berpikir kreatif siswa. Siswa hanya menerima materi yang disampaikan oleh guru.

Penggunaan keterampilan proses sains sebagai metode yang akan digunakan dalam pembelajaran Fisika pada Kurikulum ini dapat mengubah pola proses pembelajaran Fisika di kelas yang selama ini Teacher Centered menjadi Student Centered. Metode ini selain bisa membuat siswa menjadi lebih aktif juga dapat membiasakan siswa untuk bersikap ilmiah. Sehingga diharapkan kemampuan berpikir kreatif siswa meningkat dan prestasi belajar siswa juga semakin baik.

Banyak faktor lain yang dapat berpengaruh terhadap mutu pendidikan. Guru memiliki pengaruh besar terhadap kemampuan siswa dalam membentuk dan memahami suatu konsep serta hasil belajar siswa. Untuk mempermudah dan memfasilitasi guru dalam berinteraksi dengan siswa maka diperlukan sumber belajar yang dijadikan sebagai panduan yang sesuai dengan pembelajaran yang akan dilakukan. Dengan adanya bahan ajar ini diharapkan dapat membantu dalam mencapai tujuan pembelajaran.

Banyak sumber belajar yang dapat dijadikan sebagai bahan ajar dalam pembelajaran seperti tempat, benda, orang, bahan, buku, peristiwa, dan fakta. Itu semua tidak akan menjadi sumber belajar yang bermakna bagi siswa maupun guru apabila tidak diorganisasi melalui satu rancangan yang memungkinkan seseorang dapat memanfaatkannya sebagai bahan ajar. Sehingga penting bagi guru untuk terus mengembangkan media sebagai penunjang pembelajaran. Pengembangan yang dimaksud adalah pengembangan modul. Modul berperan sebagai suplemen atau buku penunjang siswa untuk belajar mandiri. Modul berperan sebagai pelengkap sumber belajar siswa.

Faktor yang diungkapkan di atas memberi kesimpulan bahwa perlu adanya suatu inovasi dalam proses pembelajaran, salah satunya adalah dengan pembuatan bahan ajar sesuai dengan karakteristik materi yang akan disampaikan. Menurut Prastowo (2014 : 16) bahwa "bahan ajar merupakan segala bahan (baik informasi, alat, maupun teks) yang disusun secara sistematis, yang menampilkan sosok utuh dari kompetensi yang akan dikuasai peserta didik dan digunakan dalam proses pembelajaran dengan tujuan perencanaan dan penelaahan implementasi pembelajaran". Pendapat tersebut menjelaskan bahwa dalam suatu bahan ajar harus terdapat kesesuaian dengan karakteristik masing-masing materi.

Anderson cit. Sukiman (2012: 28) menyatakan bahwa "media pembelajaran adalah media yang memungkinkan terwujudnya hubungan langsung antara karya seorang pengembang mata pelajaran dengan para siswa". Salah satu media pembelajaran yang dapat digunakan siswa untuk belajar mandiri adalah dalam bentuk modul. "Modul adalah sebuah bahan ajar yang disusun secara sistematis dengan bahasa yang mudah dipahami oleh peserta didik sesuai tingkat pengetahuan dan usia mereka, agar mereka dapat belajar sendiri (mandiri) dengan bantuan atau bimbingan yang minimal dari pendidik" (Prastowo, 2014:106).

Pembelajaran fisika dengan menggunakan pendekatan keterampilan proses sains akan terlaksana lebih baik jika didukung dengan modul dengan pendekatan keterampilan proses sains, sehingga dapat dengan mudah mencapai tujuan pembelajaran yang diharapkan. Tujuan pembelajaran yang dimaksud tidak hanya mencakup kemampuan pengetahuan, namun juga mencakup kemampuan sikap dan keterampilan. Dengan demikian, diharapkan kemampuan berpikir kreatif siswa dan prestasi belajar fisika semakin meningkat.

\section{Metode Penelitian}

Penelitian ini merupakan penelitian dan pengembangan (research and development $/ \quad R \quad \& \quad D)$ yang bertujuan untuk mengembangkan modul fisika melalui pendekatan keterampilan proses sains pada materi listrik dinamis bagi siswa kelas X SMA, mengetahui kelayakan modul, dan meningkatkan kemampuan berpikir kreatif siswa setelah menggunakan modul fisika melalui pendekatan keterampilan proses sains yang dikembangkan. Model yang digunakan 
sebagai dasar untuk mengembangkan modul fisika melalui pendekatan keterampilan proses sains ini merupakan hasil adaptasi model 4-D (four-D model) yang dikemukakan oleh Thiagarajan (1974 : 5).Prosedur pengembangan modul fisika melalui pendekatan keterampilan proses sains menggunakan model 4-D. Model 4-D meliputi define, design, develope, and disseminate.

Desain eksperimen yang digunakan adalah one group pretest and posttest, sehingga penelitian hanya melibatkan sekelompok subjek yang diberi pretest sebelum dikenai perlakuan, dan posttest setelah dikenai perlakuan untuk diketahui hasil akibat perlakuan tersebut.

Metode pengumpulan data yang digunakan pada penelitian dan pengembangan modul fisika dengan pendekatan keterampilan proses sains pada materi listrik dinamis adalah teknik tes, angket, dan observasi. Teknik tes dilakukan menggunakan instrumen penilaian aspek kognitif (instrumen soal diintegrasi dengan indikator kemampuan berpikir kreatif) yang telah dianalisis menggunakan Microsoft Excel. Berdasarkan analisis yang dilakukan, instrumen tes memenuhi kriteria valid dan reliabel. Teknik angket dilakukan menggunakan instrumen angket kebutuhan, angket respon, dan lembar validasi. Angket kebutuhan dan respon telah divalidasi oleh pembimbing penelitian, sedangkan lembar validasi menggunakan instrumen dengan kriteria penilaian. Teknik observasi dilakukan untuk memperoleh penilaian sikap, keterampilan siswa dan keterlaksanaan sintaks pembelajaran. Instrumen yang digunakan pada penilaian sikap, dan keterampilan adalah lembar observasi yang disesuaikan dengan indikator yang akan muncul dalam pembelajaran menggunakan skala Likert 4. Lembar observasi telah divalidasi oleh pembimbing.

Data yang diperoleh pada penelitian dan pengembangan modul fisika dengan pendekatan keterampilan proses sains untuk siswa SMA/MA kelas $\mathrm{X}$ pada materi listrik dinamis adalah data validasi ahli (materi, media, bahasa dan instrumen), praktisi pendidikan dan teman sejawat, nilai pretest posttest, nilai sikap dan keterampilan, angket respon serta angket diseminasi. Data validasi ahli, praktisi pendidikan dan teman sejawat, angket respon serta angket diseminasi dianalisis menggunakan kategori skala empat. Nilai pretest dan posttest dianalisis dengan uji $\mathrm{t}$ berpasangan dan uji n-gain. Nilai sikap dan keterampilan dianalisis dengan melakukan tabulasi nilai yang dikonversi menjadi persentase.

\section{Hasil Penelitian dan Pembahasan}

Penelitian ini merupakan penelitian dan pengembangan (research and development / $R$ $\& D$ ) yang bertujuan untuk mengembangkan modul fisika melalui pendekatan keterampilan proses sains pada materi listrik dinamis bagi siswa kelas X SMA, mengetahui kelayakan modul, dan meningkatkan kemampuan berpikir kreatif siswa setelah menggunakan modul fisika melalui pendekatan keterampilan proses sains yang dikembangkan. Model yang digunakan sebagai dasar untuk mengembangkan modul fisika melalui pendekatan keterampilan proses sains ini merupakan hasil adaptasi model 4-D (four- $D$ model) yang dikemukakan oleh Thiagarajan (1974 : 5). Prosedur pengembangan modul fisika melalui pendekatan keterampilan proses sains menggunakan model 4-D. Model 4-D meliputi define, design, develope, and disseminate. Setiap tahapan menunjukkan hasil sebagai berikut.

\section{Define}

Tahap penelitian dan pengumpulan informasi dilakukan dengan studi pustaka dan survei lapangan. Hasil studi pustaka menunjukkan bahwa nilai Ujian Nasional tahun 2013/2014 pada materi kelistrikan di SMA Negeri 1 Sekampung masih di bawah rata-rata nilai nasional dan provinsi. Hasil survei lapangan menunjukkan bahwa: 1) pembelajaran fisika di SMA Negeri 1 Sekampung belum menggunakan bahan ajar yang sesuai dengan kurikulum tingkat satuan pendidikan (KTSP), 2) pembelajaran fisika belum menggunakan pembelajaran berbasis keterampilan proses sains, 3) belum melatih siswa pada kemampuan berpikir kreatif, serta 
4) materi pada bahan ajar yang digunakan belum memuat materi yang lengkap.

Hal ini juga dilakukan oleh Sukardiyono (2013) dalam mengumpulkan informasi proses pembelajaran fisika pada penelitiannya yakni dengan studi literatur dan studi lapangan sehingga diperoleh deskripsi proses pembelajaran di lapangan.

Hasil penelitian menuju pada kesimpulan bahwa untuk mencapai KKM pada materi listrik dinamis dapat dikembangkan modul fisika dengan pendekatan keterampilan proses sains. Pencapaian KKM meliputi aspek pengetahuan, sikap dan keterampilan.

\section{Design}

Desain menurut Oemar Hamalik cit Daryanto (2013: 11) adalah suatu petunjuk yang memberikan dasar, arah, tujuan, dan teknik yang ditempuh dalam memulai dan melaksanakan suatu kegiatan. Tahap perancangan dilakukan dengan penyusunan matrik pola keterkaitan antara kegiatan di modul dengan keterampilan proses sains dan kemampuan berpikir kreatif, SK, KD dan indikator materi listrik dinamis disesuaikan dengan KTSP yang berlaku di sekolah SMA Negeri 1 Sekampung, kedalaman materi listrik dinamis yang akan dimasukkan dalam modul.

\section{Develop}

Tahap Pengembangan Produk Awal dilakukan dengan membuat draf modul fisika dengan pendekatan keterampilan proses sains, instrumen penelitian \{silabus, RPP, lembar angket, lembar validasi (beserta rubrik penilaian), lembar observasi hasil belajar afektif dan psikomotorik (beserta rubrik penilaian), dan soal evaluasi sebagai hasil belajar kognitif (11 soal kemampuan berpikir kreatif)\}. Instrumen penelitian \{angket keterbacaan modul, angket diseminasi produk, lembar validasi (beserta rubrik penilaian), lembar observasi hasil belajar afektif dan psikomotorik\} menggunakan skala likert 4 . Instrumen soal berpikir kreatif disusun dalam bentuk isian. Soal dianalisis dengan program excel dan SPSS 16. Validasi butir soal dinilai dengan validitas isi. Hasil analisis menunjukkan 11 soal valid dengan revisi. Reliabilitas soal dianalisis dengan Alpha. Soal dikatakan reliabel jika nilai reliabilitas lebih besar dari 0,7. Hasil analisis dari 11 soal yang valid didapatkan nilai sebesar 0,91 , jadi soal reliabel. Analisis indek kesukaran didapatkan 11 soal sedang. Analisis daya beda didapatkan 11 soal baik. Berdasarkan analisis validitas, reliabilitas, taraf kesukaran dan daya beda didapatkan 11 instrumen soal yang siap digunakan.

Tahap Uji Coba Produk Awal merupakan tahap dilakukan validasi oleh 2 ahli materi, 2 ahli media, 2 ahli bahasa (guru fisika) dan 2 teman sejawat. Menurut Daryanto (2013: 23) validasi dilakukan dengan cara meminta bantuan ahli yang menguasai kompetensi yang dipelajari. Validasi materi diperoleh rata-rata presentase sebesar 77,22\% dari skor ideal. Berdasarkan hasil validasi diketahui bahwa kesesuaian materi dengan kompetensi dasar, kebenaran konsep, keakuratan fakta, koherensi dan keruntutan alur pikiran, kesesuaian contoh yang digunakan dengan materi, materi mudah dipahami, kebaharuan materi dan kesesuaian dengan perkembangan psikologi anak usia SMA memiliki kriteria "Baik". Pada validasi media diperoleh rata-rata presentase sebesar $80,38 \%$ dari skor ideal. Maka dari validasi media (aspek penyajian) modul memiliki kriteria "Sangat Baik". Validasi bahasa dilakukan oleh ahli bahasa dengan rata-rata presentase yang diperoleh sebesar $75 \%$ dari skor ideal. Berdasarkan kategori nilai skala 4, maka dari aspek bahasa, modul fisika dengan pendekatan keterampilan proses sains memiliki kriteria "Baik". Validasi oleh ahli instrumen berupa validasi instrumen soal kemampuan berpikir kreatif yang dibutuhkan dalam proses uji coba lapangan luas. Soal kemampuan berpikir kreatif dilakukan dengan mengisi check list pada lembar validasi instrumen soal kemampuan berpikir kreatif. Validasi instrumen tes diperoleh rata-rata presentase sebesar $73 \%$ dari skor ideal. Berdasarkan kategori nilai skala 4 menunjukkan bahwa soal tes (dalam aspek materi, konstruksi dan bahasa) memiliki kriteria "Baik".

Tahap Revisi Produk I dilaksanakan sesuai dengan saran dan masukan dari para 
ahli, praktisi dan teman sejawat mengenai keseluruhan modul. Materi yang diperbaiki adalah dalam perumusan matematis disesuaikan dengan definisi atau konsepkonsep fisika. Visualisai modul yang diperbaiki adalah dari segi gambar cover supaya lebih menarik, jelas dan sesuai, jenis huruf yang digunakan, sumber pengambilan gambar dan kajian harus dicantumkan sumber pengambilannya, serta penggunaan kalimat supaya menggunakan kalimat yang baik dan benar, sehingga mudah dipahami oleh siswa. Perangkat yang menunjang modul diperbaiki dengan menyesuaikan waktu pembelajaran yg ada di silabus dan RPP dan untuk instrumen soal diperbaiki dengan menambahkan keterangan pada gambar, menggunakan kalimat yang mudah dipahami oleh siswa dan jawaban yang kurang tepat diperbaiki. Hasil dari praktisi pendidikan berupa perbaikan isi yang harus disesuaikan dengan tingkat kemampuan siswa kelas $\mathrm{X}$, dan perhatikan tanda baca titik, koma, tanya saat membuat kalimat bertujuan supaya siswa mudah memahami kalimat tersebut.

Tahap Uji Coba Lapangan Terbatas dilakukan kepada 10 orang siswa dari kelas $\mathrm{X}_{5}$ di SMA Negeri 1 Sekampung. Pada tahap ini bertujuan untuk mendapatkan penilaian, saran, dan tanggapan dari siswa terhadap modul fisika yang dikembangkan, data yang didapatkan kemudian dirata-rata. Hasil penilaian menunjukkan presentase rata-rata keseluruhan sebesar $78 \%$ dari skor ideal, berada pada kategori "Baik".

Tahap Revisi Produk II dilakukan berdasarkan saran dan pendapat siswa ketika pelaksanaan uji coba lapangan terbatas. Saran yang didapatkan, yaitu beberapa siswa yang memberikan saran pada penggunaan bahasa yang masih menyulitkan siswa, tetapi ada siswa juga berpendapat bahasa mudah dipahami, sehingga peneliti mengkaji kembali modul mengenai keterbacaan yang masih sulit dipahami siswa. Gambar yang kurang jelas diganti dengan gambar yang lebih jelas. Saran yang diberikan siswa pada uji coba lapangan terbatas hanya sebatas saran teknis penyajian modul, sehingga tidak menyangkut konten dari keseluruhan modul.
Tahap uji lapangan operasional dilakukan kepada 30 siswa kelas $\mathrm{X}_{6}$ di SMA Negeri 1 Sekampung. Pada tahap ini diperoleh data pretest, posttest, nilai afektif dan psikomotorik sesudah menggunakan modul fisika, dan respon siswa terhadap modul fisika yang dikembangkan. Berdasarkan data pretest dan posttest diketahui bahwa hasil belajar siswa meningkat. N-gain dari pretest dan posttest tersebut sebesar 0,7 termasuk pada kriteria sedang.

Hal ini sesuai dengan pendapat Novak dan Levinger cit Maria (2011) mengatakan "how to learn atau thinking to learn, learning to think". Jika pengajar mampu mengajarkan keterampilan berpikir tingkat tinggi, maka pembelajar akan memiliki kemampuan berpikir kreatif yang sangat dibutuhkan dalam membangun kepribadian yang mandiri yang mampu mengelola sendiri proses belajarnya (self regulated learning), dan mengkonstruksi sendiri pengetahuannya.

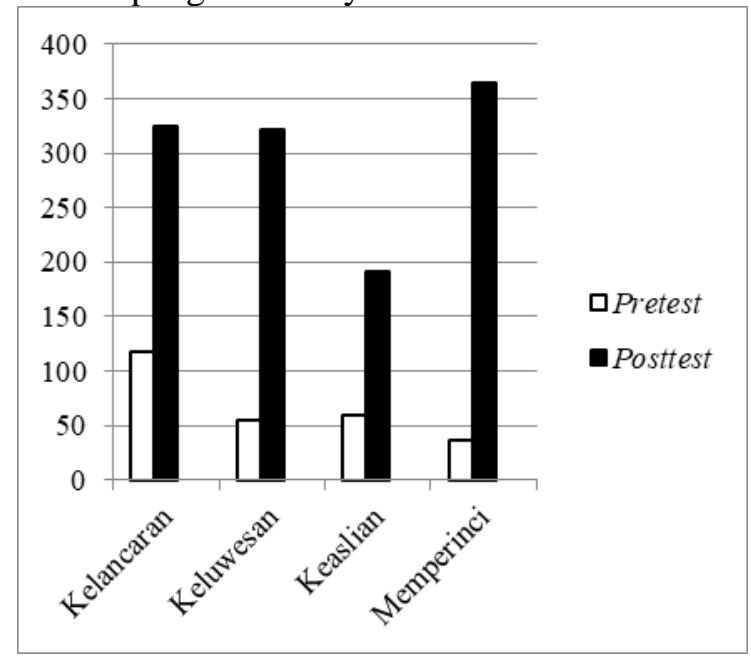

Gambar 1. Peningkatan Kemampuan Berpikir Kreatif Siswa pada Uji Lapangan Operasional

Penilaian afektif dan psikomotorik yang dilakukan oleh guru fisika dan observer. Hasil belajar afektif siswa terdapat peningkatan. Hal tersebut menunjukkan bahwa hasil belajar afektif siswa (rasa ingin tahu, kerja keras, jujur, peduli dan kreatif) meningkat seiring dengan pelaksanaan pembelajaran menggunakan modul. Hasil belajar psikomotor siswa juga mengalami peningkatan setelah penerapan modul fisika pada pembelajaran. Kenaikan hasil belajar 
psikomotorik siswa (menyiapkan alat, merangkai percobaan dan mengomunikasikan) disebabkan pada pertemuan selanjutnya siswa sudah terbiasa melakukan kegiatan yang sesuai dengan indikator dengan baik.

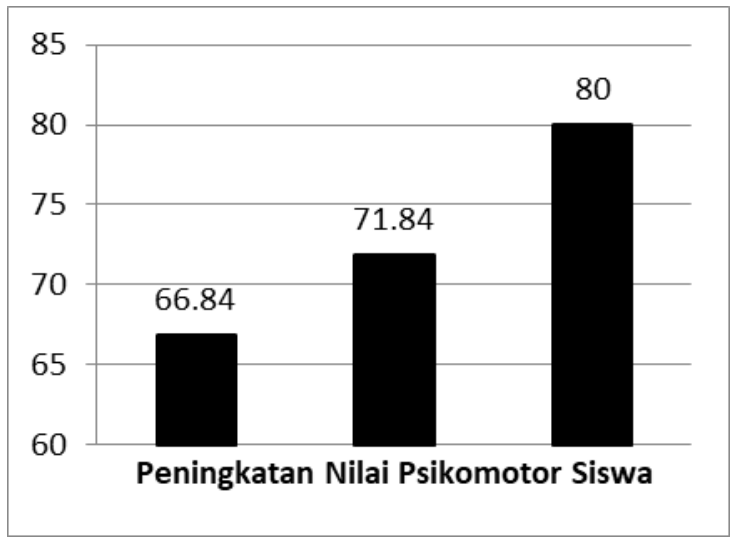

Gambar 2. Hasil Belajar Psikomotor Uji Lapangan Operasional

Sedangakan hasil belajar afektif siswa ditunjukkan pada Gambar 4.

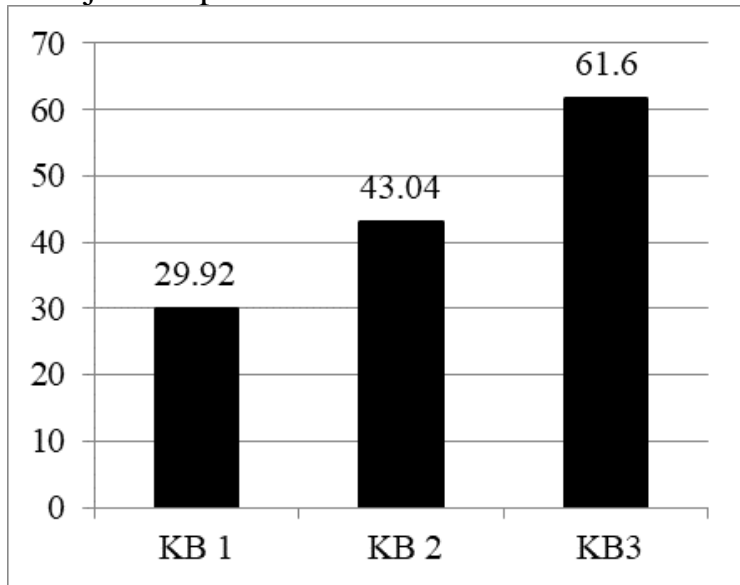

Gambar 3. Hasil Belajar Afektif Uji Lapangan Operasional

Uji lapangan operasional yang menunjukkan peningkatan hasil belajar (kognitif (berpikir kreatif), psikomorik dan afektif) setelah menggunakan modul fisika dengan pendekatan keterampilan proses sains sesuai dengan hasil penelitian yang telah dilakukan E. Rahayu dkk (2011). Menurut E. Rahayu dkk (2011) penerapan pembelajaran dengan pendekatan keterampilan proses dapat meningkatkan hasil belajar dan kemampuan berpikir kreatif siswa.

Tahap revisi produk akhir dilakukan berdasarkan pada tahap uji lapangan operasional, yaitu tanggapan dan saran mengenai modul yang telah digunakan siswa dalam kegiatan pembelajaran, antara lain: modul fisika sudah bagus, gambar dan materi sudah lengkap, bahasa yang digunakan mudah dipahami, kegiatan yang ada pada modul memudahkan siswa untuk menemukan konsep fisika dengan sendiri, soal evaluasi sudah bagus karena sudah terdapat kunci jawaban dan modul mudah dipahami baik isi, materi, dan soal. Hasil tanggapan siswa terhadap modul sudah baik, sehingga tidak perlu dilakukan revisi kembali dan sudah layak untuk digunakan.

\section{Disseminate}

Tahap diseminasi dilaksanakan untuk menyebarkan produk modul ke sekolah yang ada di Kabupaten Lampung Timur dan sekitarnya. Keterbatasan waktu, biaya, dan jarak antar sekolah yang jauh, sehingga tahap diseminasi dilakukan hanya pada 6 guru fisika dari 5 sekolah di kabupaten Lampung Timur dan sekitarnya (SMAN 1 Sekampung, SMAN 2 Sekampung, SMAN 1 Batanghari, MA Ma'arif 5 Sekampung dan SMAN 5 Metro), yang akan diambil datanya berupa penilaian dan tanggapan guru terhadap modul fisika dengan pendekatan keterampilan proses sains. Hasil tanggapan oleh guru sebagai berikut: a) Format Penulisan perlu diperbaiki agar lebih menarik dan lebih mudah untuk dibaca, b) Ilustrasi gambar masih perlu dibuat semenarik mungkin agar anak-anak punya keinginan untuk selalu membuka materi fisika c) Modul sudah layak digunakan.

Hasil tanggapan guru diperjelas dengan penilaian yang didapatkan saat kegiatan diseminasi dilakukan. Data yang didapatkan akan dirata-rata berdasarkan aspek isi modul, penyajian, dan keterbacaan modul. Hasil keseluruhan persentase rata-rata yang diperoleh sebesar $77,87 \%$ dari persentase keidealan dan dikategorikan relevan, sehingga modul sudah layak untuk dijadikan buku ajar yang baru bagi guru di sekolah. 
Hal ini sama dengan yang dilakukan oleh Sukardiyono (2013) dalam penelitiannya yakni disseminate dilakukan dengan menyosialisasikan hasil penelitian ke guru fisika yang lain. Peneliti berharap agar guru fisika tersebut mau mengimplementasikan hasil penelitian dalam proses pembelajaran di kelas.

\section{Kesimpulan dan Rekomendasi}

\section{Kesimpulan}

Karakteristik pengembangan modul fisika dengan pendekatan keterampilan proses sains untuk meningkatkan kemampuan berpikir kreatif siswa kelas X SMA/MA yaitu menggunakan teknik R\&D (research and development) dari Thiagarajan (1974: 5) termodifikasi melalui 4 tahap. Prosedur pengembangan modul fisika, yaitu integrasi antara pendekatan keterampilan proses sains yang akan mewarnai modul dengan kemampuan berpikir kreatif. Sintaks keterampilan proses sains dapat menguatkan kemampuan berpikir kreatif siswa yang dirancang pada pola keterkaitan sebagai dasar dan warna modul yang dikembangkan.

Modul fisika dengan pendekatan keterampilan proses sains layak digunakan sebagai bahan ajar baru di sekolah, kelayakan modul didasarkan atas penilaian terhadap modul, yaitu:

a. Hasil uji coba produk awal berdasarkan validasi teman sejawat, guru fisika, ahli bahasa, ahli media dan ahli materi didapatkan rata-rata persentase sebesar $78 \%$ dikategorikan "Baik".

b. Hasil uji coba lapangan terbatas yang dilakukan penilaian oleh 10 siswa yang didapatkan rata-rata persentase sebesar 78\% dikategorikan "Baik".

c. Hasil uji lapangan operasional yang dilakukan penilaian terhadap 30 siswa dan rata-rata persentase sebesar $73 \%$ dikategorikan "Baik".

d. Hasil diseminasi oleh 6 guru fisika di Kabupaten Lampung Timur dan sekitarnya, dengan rata-rata presentase penilaiannya sebesar $82,5 \%$ dikategorikan "Sangat Baik".

Secara keseluruhan rata-rata persentase kualitas modul fisika dengan pendekatan keterampilan proses sains sebesar 77,87\% dengan kategori "Baik".

Modul fisika dengan pendekatan keterampilan proses sains efektif digunakan sebagai bahan ajar baru di sekolah, keefektifan modul didasarkan atas:

a. Modul fisika dengan pendekatan keterampilan proses sains efektif digunakan sebagai bahan ajar baru, efektivitas modul didasarkan atas hasil perhitungan $N$-gain yang ditinjau dari kenaikan hasil tes kemampuan berpikir kreatif siswa (hasil belajar kognitif) sebesar 0,7 yang dikategorikan "Sedang",

b. Hasil belajar afektif dan psikomotor siswa juga mengalami kenaikan menjadi semakin membaik dari pertemuan sebelumnya.

\section{Rekomendasi}

Berdasarkan kesimpulan di atas, rekomendasi yang diajukan yaitu:

\section{Guru}

Guru harus memahami karakteristik pendekatan pembelajaran yang digunakan sebelum menerapkannya pada pembelajaran di kelas.

\section{Peneliti}

Hasil penelitian ini dapat digunakan sebagai acuan untuk mengembangkan penelitian sejenis, terutama penelitian pengembangan modul dalam pembelajaran fisika.

\section{Daftar Pustaka}

Daryanto. (2013). Menyusun Modul Bahan Ajar untuk Persiapan Guru dalam Mengajar. Yogyakarta: Gava Media.

Maria, Eni. (2011). Analisis Kemampuan Berpikir Kreatif Siswa dan Hubungannya dengan Hasil Belajar Kimia pada Konsep Termokimia di Kelas XI IPA SMA N 10 Kota Jambi. Skripsi. Universitas Jambi. (Unpublished).

Prastowo, A. (2014). Panduan Kreatif Membuat Bahan Ajar Inovatif. Yogyakarta : DIVA Press. 
JURNAL INKUIRI

ISSN: 2252-7893, Vol. 7, No. 1, 2018 (hal 29-38)

http://jurnal.uns.ac.id/inkuiri

Rahayu, E., dkk. (2011). Pembelajaran Sains

Dengan Pendekatan Keterampilan

Proses Untuk Meningkatkan Hasil

Belajar Dan Kemampuan Berpikir

Kreatif Siswa. Jurnal Pendidikan

Fisika Indonesia. ISSN: 1693-1246, 2011 (33-37).

Sukardiyono dan Yeni Ristya Wardani. (2013). Pengembangan Modul Fisika Berbasis

Kerja Laboratorium dengan

Pendekatan Science Process Skills untuk Meningkatkan Hasil Belajar Fisika Siswa. Jurnal Pendidikan Matematika dan Sains, 1(2), 185-195.

Sukiman. (2012). Pengembangan Media Pembelajaran. Yogyakarta: Pedagogia.

Thiagarajan \& Semmel. (1974). Instructional development for training teacher of exceptional children. Bloomington Indiana: Indiana University 
JURNAL INKUIRI

ISSN: 2252-7893, Vol. 7, No. 1, 2018 (hal 29-38)

http://jurnal.uns.ac.id/inkuiri 